\title{
Does Exposure to Nitrate in Drinking Water Contribute Anything the Effect of Water Chlorination on Children Methemoglobin Levels?*
}

\author{
Mina Sadeq ${ }^{1}$, Redouane Abouqal $^{2}$, Benaissa Attarassi $^{3}$, Mohammed Lakranbi $^{4}$, Rajae El Aouad ${ }^{1}$, \\ Larbi Idrissi ${ }^{1}$ \\ ${ }^{1}$ Department of Toxicology, Industrial Hygiene and Environmental Health, National Institute of Hygiene, Rabat, Morocco; \\ ${ }^{2}$ Laboratory of Biostatistics, Clinical Research and Epidemiology, Faculty of Medicine and Pharmacy, Rabat, Morocco; ${ }^{3}$ Department \\ of Biology, Faculty of Science, Ibn Tofail University, Kenitra, Morocco; ${ }^{4}$ Sala El Jadida Health Center, Ministry of Health, Salé, \\ Morocco. \\ Email: mina.sadeq@gmail.com
}

Received November $14^{\text {th }}, 2011$; revised December $16^{\text {th }}, 2011$; accepted January $6^{\text {th }}, 2012$

\begin{abstract}
Previous studies showed contradictory findings regarding the relationship between nitrate in drinking well-water and abnormal methemoglobin (MetHb) level ( $>2 \%$ ) among children. We studied the effect of water chlorination in this relationship in children aged up to 7. 240 subclinical children participated in this cross-sectional study. Water nitrate was analyzed for each participant, and so was blood MetHb. Analysis of two water nitrate exposure levels $(<50$ and $>50$ $\mathrm{mg} / \mathrm{L}$ as $\mathrm{NO}_{3}^{-}$)-other extraneous factors (Breslow-Day-Test for interaction), bivariate and multivariate analyses were performed. Abnormal MetHb levels (up to 7.9\%) were associated ( $p$-value $=0.020$ ) with exposure to drinking water nitrate. Only water chlorination was an effect modifier. Among those who do not disinfect water, the prevalence of abnormal MetHb for those with nitrate level $>50 \mathrm{mg} / \mathrm{L}$ was 4.95 ( $p$-value $=0.001,95 \% \mathrm{CI}=[1.92-12.79]$ ) times the prevalence for those with nitrate level $<50 \mathrm{mg} / \mathrm{L}$. Whereas, among those who do disinfect water, the prevalence for those with high nitrate levels was only 1.38 ( $p$-value $=0.435,95 \% \mathrm{CI}=[0.62-3.07])$ times the prevalence of those with low nitrate levels. The biological plausibility of a relationship between waterborne microorganisms, drinking water nitrate, drinking water chlorination, and development of an abnormal MetHb level needs to be further explored.
\end{abstract}

Keywords: Methemoglobin; Drinking Water; Nitrate; Chlorine; Children

\section{Introduction}

"The ferrous iron of hemoglobin $(\mathrm{Hb})$ is continuously exposed to high concentrations of oxygen and, thereby, is oxidized slowly to methemoglobin (MetHb), a protein unable to carry oxygen. To restore $\mathrm{Hb}$ function, MetHb (ferrihemoglobin) must be reduced to $\mathrm{Hb}$ (ferrohemoglobin). Under physiological conditions, MetHb reduction is accomplished mainly by red cell NADH-cytochrome $b_{5}$ reductase so efficiently that there are insignificant amounts of MetHb in the blood circulation" [1]. The normal Met$\mathrm{Hb}$ level was set as $2 \%$ of total Hemoglobin $(\mathrm{Hb})$ [2]. However, MetHb formation can be increased due to oxidant agents [1] such as drinking water nitrate [3], nitrate in some vegetables [1,4-6], nitrite used as food preservative $[4,7]$, some medications $[5,8,9]$, or to some household chemicals $[1,5,6]$.

The health-based guideline value for nitrate in drink-

\footnotetext{
*This work was supported by WHO-EMRO (project TSA 04/6).
}

ing water of $50 \mathrm{mg} / \mathrm{L}$ as $\mathrm{NO}_{3}^{-}$is based on epidemiological evidence for methemoglobinemia in infants, which results from short-term exposure and is protective for bottled-fed infants and, consecutively, other part of the population [3]. However, private water systems in Morocco and elsewhere are not required to meet this standard. Furthermore, the effect of nitrate in infants is well known [3] but less is known about the effect of nitrate in drinking water on the development of abnormal MetHb levels in children particularly with chronic exposure and when no methemolobinemia-related clinical symptom has been detected.

Previous available studies $[10,11]$ related to $\mathrm{MetHb}$ levels in children showed contradictory findings (Table 1), suggesting the involvement of potential extraneous factors on the relationship between nitrate in drinking water and MetHb level. As well-waters in rural areas may be contaminated with both nitrate as a consequence of agricultural activities, and microorganisms particularly 
Table 1. Contradictory findings related to drinking water nitrate-MetHb level relationship among children.

\begin{tabular}{cccc}
\hline Region & {$\left[\mathrm{NO}_{3}^{-}\right] \mathrm{mg} / \mathrm{L}$} & Study population & MetHb level \\
\hline USA $^{9}$ & & 102 children aged & \\
& & $1-8$ years & normal $(<2 \%)$ \\
& $>44$ & & $\operatorname{normal}(<2 \%)$ \\
& $>100$ & a children less than 8 & \\
India $^{10}$ & & years & abnormal $(>2 \%)$ \\
& $26-50$ & & abnormal $(>2 \%)$ \\
& $>50$ (up to 459$)$ & & \\
\hline
\end{tabular}

from septic tanks, we wondered whether water disinfection with chlorine contributes anything the effect of exposure to nitrate in drinking water on children MetHb levels. To our knowledge, this extraneous factor has not previously been investigated. This study aimed at investigating into this, taking into consideration other extraneous factors of methemoglobinemia.

\section{Methods}

\subsection{Study Design and Population}

A cross-sectional study was carried out in a semi-rural region that consists of four areas, and whose population (Total population $=8670$ people) $[12]$ uses well water for their daily needs. Housing and living conditions are similar. Some households have their own wells while others use communal wells that are actually private wells whose owners share with their close neighbors. Potential sources of nitrate in water are chemical fertilizers (different types of urea and ammonium nitrate) that are widely used and septic tanks that are common in the area. Vegetables are provided from a local market. Some are grown locally and sold at the same market. Two health centers provide medications, health care, and vaccination without charge to the source population.

The target population was infants and young children aged 1 - 7 years whose approximate total number was 1894 [12]. The calculated sample size [13] to detect 50\% (the hypothesized frequency) of methemoglobinemia with $95 \%$ confidence was 320 .

\subsection{Approvals}

This study was conducted with approvals of the Ministry of Health and the Home Office for ethic issues.

\subsection{Selection and Recruitment}

Three of the four study areas were small. All households, there, having children who were less than 7 years of age, were invited to participate. Selection was performed separately in each of the three study area to insure repre- sentativeness. As to the forth remaining study area and due to the geographic spread, 37 wells were chosen at random and all households having children that used those wells for drinking water were invited to participate in the study. Parents who agreed to participate provided written informed consent.

\subsection{Physical Examination}

A study physician conducted physical examinations to screen for taken medications, use of herbs, and household chemicals, that could affect MetHb level, acute diarrhea (current and antecedent one) as infection that is thought to cause methemoglobinemia [14,15], hypertension, heart disease, regular vitamin $\mathrm{C}$ intake which has a protective effect [16,17], weight, height, and signs (noise and tips of ears, around the month and eyes, and fingers can appear blue from lack of oxygen) and symptoms including cyanosis, headaches, fatigue and dizziness, that depend on MetHb level.

\subsection{Interviews}

At enrollment, we asked the parents (a preliminary interview) if their child was born and grew up in the study area or has lived outside the study area. Since we were interested in chronic exposure, children who were not born and/or did not grow up in the study areas were excluded. The study participant' age was then considered as a surrogate measure for the actual exposure to nitrate.

A detailed second questionnaire was administered to the study participants' parents to collect information about water treatment with chlorine, boiling water, and storing it in containers - as indicators of microbial water quality - and breast-feeding. Information about available foods consumed by the study population - mothers/fathers of the study children were shown a selected list of foods with potentially high nitrate levels, and were asked if their child consumed each item once or more per weekwere also collected. The list consisted of vegetables that may contain nitrate (lettuce, cauliflowers, radish, celery, parsley, coriander) since they were irrigated with wellwater, foods that may contain nitrite (cured meat), and foods that was frequently consumed in the study region (carrots, orange, fruits, fish, and cheese). Potential missing information was completed when the study team visited each participant's house to collect well-water samples.

The different steps (the preliminary interview, the physical exam, the blood sampling, and the detailed second interview) were done in a successive way for each participant. None of the investigators, the physician, and the participant's parents was aware of the nitrate levels in the study well-waters. 


\subsection{Exposure Assessment}

Water samples were collected directly from wells. Pumps were flushed for at least 15 minutes until $\mathrm{pH}$ and temperature were stabilized. $\mathrm{Ph}$ and temperature were measured with portable meters (Orion model 230A. NY.US). After collection, well-waters sample polyethylene bottles were stored at $4^{\circ} \mathrm{C}$, and sent the same day to the laboratory for analysis (Department of Toxicology, National Institute of Health. Rabat. Morocco). Beside nitrate, we were interested in other chemical water contamination indicators that may contribute to high nitrate levels in drinking water due to potential bacterial water contamination-typically, organic matters are first decomposed to give ammonia, which is then oxidized to nitrite and nitrate. Water was then tested for nitrate and nitrite using spectrophotometry methods (UV-Visible A160 Shimatzu spectrophotometer-Kyoto. Japan) [18,19]. Ammonium [20] and organic matters [18,21] were also measured. The limits of detection were $0.1 \mathrm{mg} / \mathrm{L}$ for nitrate and $0.005 \mathrm{mg} / \mathrm{L}$ as $\mathrm{NO}_{2}^{-}$for nitrite. The variation coefficients were $6.68 \%$ for nitrate (inter-days), $2 \%$ for nitrite (same day), $0.4 \%$ for organic matters (inter-days and same day). Nitrate and nitrite levels in water samples were estimated against standard curves (correlation coefficients $\mathrm{R}^{2}$ were 0.9989 for nitrate and 0.9932 for nitrite). The precisions ( $\%$ of error) were $0.8 \%$ for nitrate, $4.2 \%$ for nitrite, and less than $1 \%$ for organic matters.

\subsection{Outcome Assessment}

The samples of total blood were collected by a single nurse, using vacutainers. Hemolyis was seen only in two blood samples that were excluded from further analysis. Blood sampling and analysis were completed within less than $1 \mathrm{hr}$ since MetHb is not stable. After collection, the daily 20-heparinized blood samples were stored at $4{ }^{\circ} \mathrm{C}$ and sent immediately to the laboratory for immediate analysis (Department of Toxicology. National Institute of Hygiene. Rabat. Morocco). The blood analysis for Met$\mathrm{Hb}$ was performed using the Evelyn and Malloy [22] modified method and a UV-A160 Shimatzu spectrophotometer. The limit of detection was $0.7 \%$.

\subsection{Statistical Analysis}

Statistical analyses were carried out using the statistical software SPSS 13 for Windows (SPSS Inc., Chicago, IL, USA). Frequency of categorical variables was determined for study population's characteristics and practices. Age was grouped into five categories: infants aged less than 6 months, infants aged more than 6 months but less than one year, and the remaining categories were all with approximately equal age interval. The chi-square test or the Fisher exact test (bivariate analysis) was first performed. Apart from age, all the variables were divided into two categories. All variables with a bivariate $p$-value $<0.25$ were subject to a Breslow-Day test for interaction. Finally, logistic regression (multivariate analysis) was carried out.

\section{Results}

\subsection{Descriptive Statistics}

Respect for inclusion criteria and for ethical clause some mothers were reluctant to have their infants participate in the study-downsized the sample size. Furthermore some families who use collective wells did not know whether or not the well-water is regularly disinfected with chlorine. Data related to children from these families was not considered. A total of 240 participants had complete data and covariate information. We calculated [13] the estimated power of this cross-sectional study, for the 240 participants, based on Normal approximation with continuity correction. It was equal to $84.94 \%$.

Of the 240 participants, 105 (43.8\%) were females, 13 (5.4\%) were 0 - 6 months old, $21(8.8 \%)$ were 7 - 11 months old, 69 (28.8\%) were 12 - 35 months old, and 64 (26.7\%) were 60 months old or more ( $\geq 60$ months). Overall, most children $211(87.9 \%)$ experienced antecedent acute diarrheas. 202 (84.2\%) had received medications to treat diarrhea or respiratory symptoms (cough or flu). Of these, 193 (95.5\%) used antiseptics; no taken medications were known to affect MetHb level. Regular vitamin $\mathrm{C}$ intake was not frequent. The physical examination did not indicate any sign/symptom related to methemoglobinemia, or problems with hypertension or heart disease.

Comparing users of well-waters whose nitrate levels were higher than $50 \mathrm{mg} / \mathrm{L}$ with those of well-waters whose nitrate levels were lower than $50 \mathrm{mg} / \mathrm{L}$ (Table 2), similarity was seen in gender, height, antecedent acute diarrheas, family's income, and mother's school level whereas differences were seen in weight, abnormal Met$\mathrm{Hb}$ levels, and water chlorination.

\subsection{Water Contaminants}

Bottled water use was not common among participants. Of the 240 participants, $152(63.3 \%)$ were exposed to nitrate level above $50 \mathrm{mg} / \mathrm{L}$ as $\mathrm{NO}_{3}^{-}$. Water contaminants concentrations were measured in 65 wells. Their distribution is shown in Table 3. The well-waters tested had organic matter levels below the maximum acceptable value which is $5 \mathrm{mg} \mathrm{O}_{2} / \mathrm{L}$ [23], and nitrite levels below the guideline value set at $3 \mathrm{mg} / \mathrm{L}$ as $\mathrm{NO}_{2}^{-}$for short term 
Table 2. Characteristics of the study population.

\begin{tabular}{|c|c|c|c|}
\hline \multirow{3}{*}{ Weight (kg) } & $\begin{array}{c}\text { Low exposed group } \\
\qquad \mathrm{NO}_{3}^{-}<50\end{array}$ & $\begin{array}{l}\text { High exposed group } \\
\qquad \mathrm{NO}_{3}^{-}>50\end{array}$ & $p$-value \\
\hline & $\mathrm{N}=88(36.7 \%)$ & $\mathrm{N}=152(63.3 \%)$ & \multirow{2}{*}{$<0.001$} \\
\hline & $14.7 \pm 4.3^{\mathrm{a}}$ & $15 \pm 6.6^{\mathrm{a}}$ & \\
\hline Height (m) & $0.92 \pm 0.16^{\mathrm{a}}$ & $0.92 \pm 0.19^{\mathrm{a}}$ & 0.08 \\
\hline Gender & & & 0.686 \\
\hline Female & $40(45.5)$ & $65(42.8)$ & \\
\hline Male & $48(54.5)$ & $87(57.2)$ & \\
\hline \multicolumn{4}{|l|}{ Age group (months) } \\
\hline $0-6$ & $6(6.8)$ & $7(4.6)$ & 0.652 \\
\hline $7-11$ & $5(5.7)$ & $16(10.5)$ & 0.202 \\
\hline $36-59$ & $27(30.7)$ & $46(30.3)$ & 0.945 \\
\hline$\geq 60$ & $18(20.5)$ & $46(30.3)$ & 0.09 \\
\hline MetHb level & & & 0.002 \\
\hline$<2 \%$ & $69(78.4)$ & $89(58.6)$ & \\
\hline$>2 \%$ & $19(21.6)$ & $63(41.4)$ & \\
\hline Water chlorination & & & 0.004 \\
\hline No & $51(58.0)$ & $59(38.8)$ & \\
\hline Yes & $37(42.0)$ & $93(61.2)$ & \\
\hline Antecedent acute diarrheas & & & 0.06 \\
\hline No & $6(06.8)$ & $23(15.1)$ & \\
\hline Yes & $82(93.2)$ & $129(84.9)$ & \\
\hline \multicolumn{4}{|l|}{ Income } \\
\hline$\leq 1500$ Dirhams & $56(63.6)$ & $88(88 / 144)$ & 0.382 \\
\hline > 1500 Dirhams & $15(17.0)$ & $31(31 / 46)$ & 0.526 \\
\hline Not stated & $17(19.3)$ & $33(21.71)$ & 0.660 \\
\hline \multicolumn{4}{|l|}{ Mother's school level } \\
\hline Without & $71(80.7)$ & $111(73.0)$ & 0.183 \\
\hline Primary school & $13(14.8)$ & $34(22.4)$ & 0.154 \\
\hline Secondary school & $3(3.4)$ & $6(3.9)$ & $>0.999$ \\
\hline University & $1(1.1)$ & $1(0.7)$ & $>0.999$ \\
\hline
\end{tabular}

${ }^{\mathrm{a}}$ mean \pm Standard deviation.

Table 3. Distribution of drinking water contaminants by exposure.

\begin{tabular}{|c|c|c|c|c|c|c|c|}
\hline & \multicolumn{3}{|c|}{ Low exposed group } & \multicolumn{4}{|c|}{ High exposed group } \\
\hline & \multicolumn{3}{|c|}{$\mathrm{NO}_{3}^{-}<50$} & \multicolumn{4}{|c|}{$\mathrm{NO}_{3}^{-}>50$} \\
\hline & \multicolumn{3}{|c|}{$\mathrm{n}=21$} & \multicolumn{4}{|c|}{$\mathrm{n}=44$} \\
\hline & $\mathrm{m} \pm \mathrm{SD}$ & Median & Range & $\mathrm{m} \pm \mathrm{SD}$ & Median & Range & p-value \\
\hline Nitrate & $29.74 \pm 11.03$ & 28.04 & $15.39-49.52$ & $111.60 \pm 52.43$ & 100.58 & $50.74-246.90$ & $<10-7$ \\
\hline Nitrite $^{*}$ & $0.012 \pm 0.008^{\mathrm{a}}$ & $0.010^{\mathrm{a}}$ & $0.006-0.029^{\mathrm{a}}$ & $0.013 \pm 0.008^{b}$ & $0.012 b$ & $0.006-0.029^{\mathrm{b}}$ & 0.925 \\
\hline $\mathrm{OM}$ & $0.49 \pm 0.25$ & 0.40 & $0.24-1.20$ & $0.47 \pm 0.25$ & 0.40 & $0.24-1.20$ & 0.963 \\
\hline
\end{tabular}

$\mathrm{n}=$ number of wells; ${ }^{\mathrm{a}} \mathrm{n}=8$ (the remaining values to complete $\mathrm{n}=21$ were below the limit of detection); ${ }^{\mathrm{b}} \mathrm{n}=19$ (the remaining values to complete $\mathrm{n}=44$ were below the limit of detection). 
exposure or $0.2 \mathrm{mg} / \mathrm{L}$ as $\mathrm{NO}_{2}^{-}$for chronic exposure [3]. Ammonium ion was not detected.

\subsection{MetHb Levels}

The mean MetHb level was $1.3 \% \pm 0.9 \%$ (range $0.7 \%$ $5.0 \%$, median $=0.7 \%$ ) for participants exposed to nitrate level below $50 \mathrm{mg} / \mathrm{L}$ as $\mathrm{NO}_{3}^{-}$, and $2 \% \pm 1.5 \%$ (range $0.7 \%-7.9 \%$, median $=1.4 \%$ ) for those exposed to nitrate level above $50 \mathrm{mg} / \mathrm{L}$ as $\mathrm{NO}_{3}^{-}$. The difference in means was statistically significant $\left(p<10^{-3}\right)$.

\subsection{MetHb Level in Relationship with Covariates}

Abnormal MetHb level was significantly associated with higher nitrate level in both unadjusted and adjusted analysis (Tables $\mathbf{4}$ and 6). When chlorine use was examined as a protective factor of abnormal MetHb in unadjusted analysis, it was not significantly associated with higher MetHb levels. We conducted covariates-stratified analyses on nitrate in drinking water and abnormal MetHb level. We did not retain neither covariates such as boiling drinking water, antecedent acute diarrheas, lettuce, celery, coriander, and parsley since they were not significantly associated with abnormal MetHb level ( $p$-value $>0.25$ ) nor age (a surrogate measure of the period of exposure to drinking water nitrate). Infants (0 - 6 months) were considered as a reference group since breastfeeding protects from methemoglobinemia [17]. However, the small number of infants in the current study (13 participants: 9 were only breastfed; 4 were breastfed and also used formula) did not allow us to consider the age as a potential risk factor of abnormal MetHb level. Covariates-stratified analyses revealed (results not shown except for chlorine use) that only water disinfection with chlorine (Table 5) was an effect modifier ( $p$-value of BDT for interaction was 0.044). In those who do not disinfect water with chlorine, the prevalence of abnormal MetHb for those exposed to high nitrate levels $\left(>50 \mathrm{mg} / \mathrm{L}\right.$ as $\left.\mathrm{NO}_{3}^{-}\right)$was $4.95(95 \%$ $\mathrm{CI}=1.92$ to 12.79$)$ times the prevalence for those exposed to low nitrate level $\left(\leq 50 \mathrm{mg} / \mathrm{L}\right.$ as $\left.\mathrm{NO}_{3}^{-}\right)$. However, in those who use chlorine as disinfectant, the prevalence for those with high nitrate level was only $1.38(95 \% \mathrm{CI}=$ 0.62 to 3.07) times the prevalence of those with low nitrate level. If chlorine use-stratified analysis was not conducted, chlorine use would misleadingly be referred to as "a risk factor" (Table 6).

In unadjusted analysis (Table 4), consumption of carrots, cheese, fish, cured meat, orange, or fruits was predictive of abnormal MetHb levels. This was no longer true under conditions of multivariate analysis that indicated a protective effect of consumption of radish (Table 6).

\section{Discussion}

The users of high nitrate levels in drinking water were more likely to disinfect water with chlorine (Table 2). The effects of both low and high nitrate levels were similar when chlorine was used. In its absence, the prevalence of abnormal MetHb among the exposed to high nitrate levels in drinking water was about 5 times that among the exposed to low nitrate levels (Table 4). As wells in agricultural rural areas are often dug privately and may be too close to disposal points for human and animal excreta, the risk of pollution increases not only by nitrate but also by $E$. coli and other microorganisms; since chlorine is efficient in killing many microorganisms, we deduced that, while assessing children abnormal MetHb levels, the effect of nitrate is only realized when waterborne microorganisms are also present. Indeed, it is well known that although chemically unreactive, the nitrate ion $\left(\mathrm{NO}_{3}^{-}\right)$can be reduced by microbial action to nitrite ion $\left(\mathrm{NO}_{2}^{-}\right)$that oxidizes $\mathrm{Fe}^{2+}$ of $\mathrm{Hb}$ to $\mathrm{Fe}^{3+}$. Furthermore, it has been found that some bacteria (E. coli, Salmonella typhimurium, and Klebsiella pneumoniae) produce an iron chelator [24-28]. This compound, synthesized only under conditions of iron restriction, efficiently removes iron from the iron-binding proteins and delivers it into the bacterial cell [26,27,29], which stimulates bacteria proliferation. Storing water (up to 2 days in clean vessels) did not contribute anything the effects of drinking water nitrate to the development of abnormal MetHb levels, which may support the above deduction. Further epidemiologic and toxicological studies are needed to better understand the relationship between nitrates in drinking water, water chlorination, waterborne microorganisms, and abnormal MetHb levels. It might be more efficient and less expensive to disinfect water with chlorine than to remove nitrate from water to prevent abnormal MetHb level.

Although nitrate concentrations exceeding $50 \mathrm{mg} / \mathrm{L}$ are not unusual in many developing and developed countries, few studies investigated into the effect of water chlorination on the relationship between nitrate in drinking water and development of abnormal MetHb levels in children. In India, Gupta et al. [11] (Table 1) found both low and high nitrate levels $(26,45,95,222,459 \mathrm{mg} / \mathrm{L}$ as $\mathrm{NO}_{3}^{-}$) to be associated with abnormal mean MetHb levels (respectively 8.94\%, 15.17\%, 15.13\%, 8.07\%, 15.46\% of total $\mathrm{Hb}$ ), and suggested that increased consumption of nitrate increases nitrite and free radicals (NO) production leading to irreversible cells damage and recurrent diarrhea. No information was provided regarding water chlorination or water microbial quality. In Craun et al. [11] study (Table 1) only 5 of 46 water analyses were of 
Table 4. Bivariate analysis relative to water microbiological quality, age, and food consumption.

\begin{tabular}{|c|c|c|c|}
\hline Variables & OPR & $95 \% \mathrm{CI}$ & $p$-value \\
\hline Water nitrate & 2.57 & $1.41-4.69$ & 0.002 \\
\hline Chlorine use & 1.41 & $0.82-2.42$ & 0.211 \\
\hline Storing water & 3.29 & $0.72-15.10$ & 0.125 \\
\hline Boiling water & 0.41 & $0.09-1.96$ & 0.267 \\
\hline Acute diarrhea & 0.70 & $0.32-1.55$ & 0.384 \\
\hline \multicolumn{4}{|c|}{ Age group (months) } \\
\hline $0-6$ & 1.00 & & \\
\hline $7-11$ & 2.75 & $0.47-15.96$ & 0.260 \\
\hline $12-35$ & 3.12 & $0.64-15.23$ & 0.159 \\
\hline $36-59$ & 2.69 & $0.55-13.12$ & 0.220 \\
\hline$\geq 60$ & 3.30 & $0.67-16.16$ & 0.141 \\
\hline Lettuce & 0.98 & $0.54-1.77$ & 0.944 \\
\hline Califlowers & 1.43 & $0.80-2.55$ & 0.222 \\
\hline Radish & 0.53 & $0.24-1.17$ & 0.115 \\
\hline Carrots & 1.75 & $1.01-3.01$ & 0.044 \\
\hline Celery & 1.52 & $0.68-3.39$ & 0.305 \\
\hline Cheese & 2.34 & $1.35-4.21$ & 0.003 \\
\hline Fish & 2.30 & $1.33-3.96$ & 0.003 \\
\hline Cured meat & 2.79 & $1.16-6.67$ & 0.021 \\
\hline Orange & 2.18 & $1.14-4.16$ & 0.019 \\
\hline Fruits & 2.31 & $1.21-4.40$ & 0.011 \\
\hline Coriander & 0.92 & $0.52-1.63$ & 0.774 \\
\hline Parsley & 0.95 & $0.53-1.68$ & 0.850 \\
\hline
\end{tabular}

$\mathrm{CI}=$ Confidence Interval; OPR $=$ Odds Prevalence Ratio

Table 5. Abnormal MetHb and water nitrate exposure, stratified by chlorine use.

\begin{tabular}{ccccc}
\hline Crude (unadjusted) & \multicolumn{2}{c}{ OPR $=2.57$} & $95 \%$ CI $=[1.41-4.69]$ & $p$-value $=0.002$ \\
\hline Covariate & \multicolumn{2}{c}{ Water nitrate } & Stratum specific & Chi-square for interaction \\
& Exposed & Not exposed & OPR $[95 \mathrm{CI}]$ & \\
& MetHb $>2 \%$ & MetHb $<2 \%$ & & \\
\hline Water chlorination & $(\%)$ & $(\%)$ & $1.38[0.62-3.07]$ & 0.044 \\
Yes & 75.5 & 69.1 & $4.95[1.92-11.79]$ & \\
No & 78.8 & 42.9 &
\end{tabular}

$\mathrm{CI}=$ Confidence Interval; OPR $=$ Odds Prevalence Ratio

Table 6. Multivariate analysis.

\begin{tabular}{cccc}
\hline Variables & OPR & $95 \%$ CI & -value \\
\hline Water nitrate & 3.41 & $1.21-9.58$ & 0.020 \\
Chlorine use & 3.31 & $1.07-10.24$ & 0.037 \\
Storing water & 2.30 & $0.44-12.02$ & 0.323 \\
Califlowers & 1.34 & $0.55-3.31$ & 0.520 \\
Radish & 0.30 & $0.10-0.84$ & 0.023 \\
Carrots & 1.24 & $0.52-2.97$ & 0.621 \\
Fish & 1.40 & $0.55-3.52$ & 0.480 \\
Cheese & 2.01 & $0.87-4.63$ & 0.101 \\
Cured meat & 1.46 & $0.53-4.02$ & 0.462 \\
Orange & 0.83 & $0.32-2.10$ & 0.689 \\
Fruits & 1.61 & $0.60-4.32$ & 0.342 \\
\hline
\end{tabular}

$\mathrm{CI}=$ Confidence Interval; OPR = Odds Prevalence Ratio. 
acceptable bacteriological quality according to WHO standards. In spite of this, MetHb levels were below the normal physiologic level of $2 \%$ (Table 1) in both low nitrate exposed (mean MetHb level $=0.98 \% \pm 0.18 \%$ ) and high nitrate exposed (mean MetHb level $=1.13 \% \pm 0.1 \%$ ) (Table 1). There was no trend towards higher levels of $\mathrm{MetHb}$ level in young children using wells with greater bacterial contamination. No information was provided regarding water treatment devices use (nitrate removal and others) which is a common occurrence in the USA.

The strengths of the current study include a larger sample size than in previous studies $[10,11]$ and complete data and covariate information. The study power was sufficient $(>20 \%)$ to determine a relationship between exposure to nitrate and abnormal MetHb if it exists. Selection bias can be ruled out since no information on nitrate levels or MetHb levels was available to either the participants' families or investigators prior to the study.

The present study shows that children exposed to high nitrate levels ( $>50 \mathrm{mg} / \mathrm{L}$ as $\mathrm{NO}_{3}^{-}$) in drinking water had higher MetHb levels $(>2 \%$ of the total $\mathrm{Hb})$ and vice versa. This finding was robust to adjustment for many extraneous factors (environmental, behavioral, and clinical factors). Potential causes of methemoglobinemia other than drinking water nitrate were not identified. The air quality, the socio-economic status indicators (housing and living conditions, and family income), the frequented food-markets, and the quality of health care provided by the two available health centers all were similar for both high and low exposed participants. Prescreening established that no participant in this study had been exposed to drugs (medicines or herbs) or household chemicals that may contain nitrate. Participants' families' practices such as boiling or storing water were also similar. Diarrhea is a common symptom associated with microorganisms and other factors. In the current study, the likely antecedent occurrences of acute diarrhoeas in the participants may be related to bacterial infection since only antiseptics were prescribed as efficient treatment and to sources other than drinking water since water chlorination was not statistically associated with antecedent acute diarrheas.

Our study has limitations. Chorine (Sodium Hypochlorite) is used in the well itself by hygiene service officials; otherwise, it is used in the stored well water by the population. The chlorine bottle is available in the market; the Moroccan population is taught how to disinfect stored water: a tea glass or the bottle's cup is used to measure the correct amount of disinfectant to add to the quantity of water in the water vessel. Residual chlorine levels were not tested in the current study. However, we asked for frequent continuous water chlorination use in many different ways at different occasions (during the admin- istered questionnaire, during the interviews with local public health officials, and the households' visits) to ascertain whether chlorine is or is not used.

\section{Conclusion}

Water chlorination is an effect modifier in the association: drinking well water nitrate-children methemoglobin levels. The biological plausibility of a relationship between waterborne microorganisms, nitrate exposure via drinking water, drinking water chlorination, and development of an abnormal MetHb level in childhood needs to be further explored.

\section{Acknowledgements}

The authors gratefully acknowledge C.L. Moe for comments, E. Ben Abbou for contributing to blood analyses, F. Benammi, and N. Nouari for assisting with laboratory water analyses.

\section{REFERENCES}

[1] A. Mansouri and A. A. Lurie, "Concise Review: Methemoglobinemia," American Journal of Hematology, Vol. 42, No. 1, 1993, pp. 7-12. doi:10.1002/ajh.2830420104

[2] J. P. Fréjaville, B. Christoforov, C. Bismuth, et al., "Toxicologie Clinique et Analytique," in French, 2nd Edition, Flammarion Médecine Sciences, Paris, 1971, pp. 63-64.

[3] WHO, "Nitrate and Nitrite in Drinking Water," Background Documents for Development of WHO Guidelines for Drinking-Water Quality, WHO/SDE/WSH/07.01/16, Geneva, 2007.

[4] G. L. Askew, L. Finelli, C. A. Genese, F. E. Sorhage, D. M. Sosin and K. C. Spitalny, "Boilerbaisse: An Outbreak of Methemoglobinemia in New Jersey in 1992," Pediatrics, Vol. 94, No. 3, 1994, pp. 381-384.

[5] L. M. Haddad and J. F. Winchester, "Clinical Management of Poisoning and Drug Overdose," 2nd Edition, WB Sunders, Philadelphia, 1990, pp. 1419-1431.

[6] R. O. Wright, W. J. Lewander and A. D. Woolf, "Methemoglobinemia: Ethiology, Pharmacology, and Clinical Management," Annals of Emergency Medicine, Vol. 34, No. 3, 1999, pp. 646-656. doi:10.1016/S0196-0644(99)70167-8

[7] A. Finan, P. Keenan, F. O'Donovan, P. Mayne and J. Murphy, "Methemoglobinemia Associated with Sodium Nitrite in Three Siblings," BMJ, Vol. 317, 1998, pp. 11381139. doi:10.1136/bmj.317.7166.1138

[8] R. Ash-Bernal, R. Wise and S. M. Wright, "Acquired Methemoglobinemia: A Retrospective Series of 138 Cases at Two Teaching Hospitals," Medicine (Baltimore), Vol. 83, No. 5, 2004, pp. 265-273.

doi:10.1097/01.md.0000141096.00377.3f

[9] E. Jaffe, "Methemoglobin Phathophysiology," Progress in Clinical Biological Research, Vol. 51, 1981, pp. 133-151. 
[10] G. F. Craun, D. G. Greathouse and D. H. Gunderson, "Methaemoglobin Levels in Young Children Consuming High Nitrate Well Water in the United States," International Journal of Epidemiology, Vol. 10, No. 4, 1981, pp. 309-317. doi:10.1093/ije/10.4.309

[11] S. K. Gupta, R. C. Gupta, A. K. Seth, A. B. Gupta, J. K. Bassin and A. Gupta, "Adaptation of Cytochrome-b5 Reductase Activity and Methaemoglobinaemia in Areas with a High Nitrate Concentration in Drinking Water," Bulletin of the World Health Organization, Vol. 77, No. 9, 1999, pp. 749-753.

[12] Maroc. HCP. CLAD. Haut Commissariat du Plan, Centre de la Lecture Automatique des Documents, "RGPH2004 en ligne," in French, 2006. http://clad.hcp.ma

[13] A. Dean, K. Sullivan and M. M. Soe, "OpenEpi. Open Source Epidemiologic Statistics for Public Health,” 2004. http://openepi.com

[14] A. A. Avery, "Infantile Methemoglobinemia: Reexamining the Role of Drinking Water Nitrates," Environmental Health Perspectives, Vol. 107, 1999, pp. 583-586. doi:10.1289/ehp. 99107583

[15] A. A. Avery, "Cause of Methemoglobinemia: Illness versus Nitrate Exposure," Environmental Health Perspectives, Vol. 109, 2001, pp. 12-14. doi:10.1289/ehp.109-a12

[16] M. H. Ward, T. M. deKok, P. Levallois, J. Brender, G. Gulis, B. T. Nolan and J. van Derslice "Workgroup Report: Drinking-Water Nitrate and Health-Recent Findings and Research Needs," Environmental Health Perspectives, Vol. 113, 2005, pp.1607-1614. doi: $10.1289 /$ ehp. 8043

[17] C. L. Zeman, B. Kross and M. Vlad, "A Nested CaseControl Study of Methemoglobinemia. Risk Factors in Children of Transylvania, Romania," Environmental Health Perspectives, Vol. 110, 2002, pp. 817-822. doi:10.1289/ehp.02110817

[18] J. Rodier, "L'analyse de l'eau, Eaux Naturelles, Eaux Résiduelles, eau de mer: Chimie, Physico-Chimie, bacté Riologie, Biologie," in French, Vol. 1, 5th Edition, Dunod, Paris, 1975, pp. 166-167,170-172,566-567.

[19] A. Aminot and M. Chaussepied, "Manuel des Analyses
Chimiques en Milieu Marin,” in French, CNEXO, Brest, 1983, pp. 119-124.

[20] J. Rodier, "L'Analyse Chimique et Physico-Chimique de l'eau. Eaux naturelles-Eaux Usées," in French, 2nd Edition, Dunod, Paris, 1960, pp. 78-79.

[21] D. Pradeau, "Analyse Pratique du méDicament," in French, Lavoisier, Editions Médicales Internationales (EMI), Paris, 1992, pp. 362-364.

[22] I. Sunshine, "Methodology for Analytical Toxicology," Vol. 1, CRC Press, Cleveland, 1975, pp. 245-246.

[23] Maroc. SNIMA, "Norme Marocaine Homologuée: Qualité des Eaux d'Alimentation Humaine, NM 03.7.001," in French, Service de Normalisation Industrielle Marocaine, Rabat, 2006.

[24] I. G. O'Brien and F. Gibson, “The Structure of Enterochelin and Related 2,3-Dihydroxy-N-Benzoylserine Conjugates from Escherichia coli," Biochimica \& Biophysica Acta, Vol. 215, 1970, pp. 393-402.

[25] J. R. Pollack and J. B. Neilands, "Enterobactin, an Iron Transport Compound from Salmonella Typhimurium," Biochemical and Biophysical Research Communications, Vol. 38, No. 6, 1970, pp. 989-992. doi:10.1016/0006-291X(70)90819-3

[26] H. J. Rogers, "Iron-Bonding Catechols and Virulence in Escherichia coli," Infection and Immunity, Vol. 7, No. 3, 1973, pp. 445-456.

[27] H. J. Rogers, C. Synge, B. Kimber and P. M. Bayley, "Production of Enterochelin by Escherichia coli O111," Biochimica et Biophysica Acta, Vol. 497, No. 2, 1977, pp. 548-557.

[28] H. J. Rogers, "Role of Iron Chelators, Antibodies and Iron-Bonding Proteins in Infection," In: D. Slessinger, Ed. microbiology, American Society of Microbiology, Washington DC, 1983, pp. 334-337.

[29] C. J. Carrano and K. N. Raymond, "Ferric Ion Sequestering Agents: 2.Kenetics and Mechanisms of Iron Removal from Transferring by Enterochelin and Synthetic Tricatechols," Journal of the American Chemical Society, Vol. 101, 1979, pp. 5401-5404. doi:10.1021/ja00512a047 